\title{
PEMEROLEHAN BAHASA ANAK: KAJIAN ASPEK FONOLOGI PADA ANAK USIA 2 - 2,5 TAHUN
}

\author{
Prima Gusti Yanti \\ pgustiyanti@yahoo.com \\ FKIP Universitas Muhammadiyah Prof. Dr. Hamka, Jakarta \\ JI. Tanah Merdeka, Kp. Rambutan, Ciracas, Jakarta Timur
}

Abstrak: Penelitian ini bertujuan memaparkan pemerolehan bahasa anak usia 2--2.5 tahun dari aspek fonologi yang meliputi pemerolehan vokal, pemerolehan konsonan, dan faktor yang mempengaruhi pemerolehan fonologi tersebut. Penelitian dilakukan di Jakarta pada bulan Agustus-Februari 2012. Metode yang digunakan dalam penelitian ini adalah metode kualitatif dengan pendekatan studi kasus. Sumber data diperoleh dari seorang anak yang bernama TPM. Data artikel ini dikumpulkan melalui observasi, catatan harian, dan wawancara. Temuan dalam artikel ini memperlihatkan bahwa TPM telah menguasai fonem [a], [i], [u], [e], [o], [ə], [€], dan [O]. Fonem vokal itu dikuasainya pada usia 2 tahun 1 bulan. Vokal pertama yang dikuasainya adalah vokal [a], [i], dan [u], kemudian vokal depan [i], [e], [ع], lalu vokal belakang [u], [o], [ग], dan vokal tengah [ə],[a]. Bunyi vokal rangkap yang tidak bersifat diftong juga telah dikuasai pada usia 2 tahun 3 bulan, misalnya [au], [ai] dan [ue]. Akan tetapi, diftong asli [au] dan [ai] baru dikuasainya pada usia 2 tahun 6 bulan. Sementara itu, konsonan [p], [b], [t], [d], [s], [h], [c], [j], [m], [n], [n], [l], [w], dan [y] dikuasainya dengan baik. Konsonan [t], [s], [c], [j], dan [n] sudah muncul, tetapi masih berfluktuasi dengan bunyi lain. Bunyi hambat velar [g], [k] belum diucapkan secara tepat. Bunyi [k] baru dikuasai jika terletak pada tengah dan akhir kata. Bunyi frikatif [f] dan [v] dan bunyi getar [r] belum muncul dan dikuasainya. TPM melakukan pola substitusi untuk mengucapkan fonem-fonem yang belum dikuasainya, seperti fonem [f], [v], [z], dan [x]. Munculnya berbagai variasi dalam pemerolehan fonologi TPM sebagian besar disebabkan oleh belum sempurnanya alat ucap TPM. Penelitian masih terbuka untuk penelitian pemerolehan fonologi lebih lanjut karena pemerolehan bahasa TPM belum mencapai puncak. Namun dapat juga meneliti pemerolehan bahasa pada aspek bahasa lainnya.

Kata-kata Kunci: pemerolehan bahasa, aspek fonologi, vocal, konsonan

\section{CHILD LANGUAGE ACQUISITION : THE PHONOLOGICAL STUDY OF 2-2.5 YEARS OLD CHILDREN}

\begin{abstract}
Abstrak: This article aims to explain child language acquisition 2--2.5 years of age phonological aspects which include the acquisition of vowels, consonants, and factors affecting the phonological acquisition. The research was conducted in Jakarta from August 2011 through February 2012 . The method used in this research was qualitative method with case study approach. Sources of data were obtained from TPM and these data were collected during six months of observation, diaries, and interviews. The findings in this

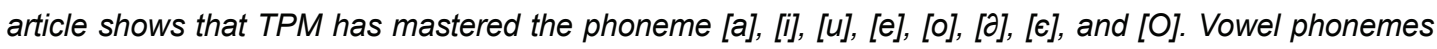
was mastered at the age of 2 years and 1 month. The first vowel that it controls is a vowel [a], [i] and [u],

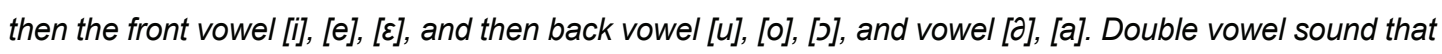
is not a diphthong also been mastered by the age of 2 years and 3 months, for example, [au], [ai] and [ue]. However, the original diphthong [au] and [ai] recently mastered at age 2 years and 6 months. Meanwhile, the consonant $[p],[b],[t],[d],[s],[h],[c],[j],[m],[n],[\eta],[l],[w]$ and $[y]$ mastered well. Consonant $[t],[s],[c]$, [j] and [ $\mathrm{g}]$ has appeared, but still fluctuates with another sound. The sound resistor velar [g] and [k] are not pronounced properly. The sound [k] is mastered if located in the middle and end of words. Sound fricative [f] and [V] and trill [r] has not yet emerged and mastered. TPM perform substitution pattern to pronounce phonemes had not conquered, such as phonemes [f], $[\mathrm{V}],[\mathrm{z}]$, and $[\mathrm{x}]$. The appearance of a wide range of variation in her phonological acquisition largely is caused by the incomplete of her speech organ. Research is still open for further research the acquisition of phonology because language acquisition TPM has yet to reach the Summit. But it can also examine language acquisition on aspects of other languages
\end{abstract}

Keywords: language acquisition, phonological aspects, vocal, consonants 


\section{PENDAHULUAN}

Pemerolehan bahasa (language acquisition) termasuk ke dalam ranah (domain) psikolinguistik, yaitu ilmu bahasa yang objeknya adalah pengetahuan bahasa, pemakaian bahasa, perubahan bahasa, dan hal lain yang ada hubungannnya dengan aspekaspek tersebut. Pengetahuan bahasa bersangkut paut dengan masalah kognitif karena unsur bahasa yang diketahui dan dipahami sebenarnya berproses dalam otak. Pemakaian bahasa berkaitan dengan praktik pengetahuan bahasa, yaitu apa yang kita ketahui kita kemukakan dalam bentuk pemakaian bahasa.

Sebagai bidang yang termasuk ke dalam ranah psikolinguistik, pemerolehan bahasa akhir-akhir ini berkembang secara cepat. Hal ini disebabkan oleh adanya perubahan pendangan tentang pengajaran dan pembelajaran bahasa, serta makin gencarnya konsep universal dalam pemerolehan bahasa. Pengajaran dan pembelajaran bahasa tidak hanya bertumpu pada pandangan bahwa bahasa itu adalah seperangkat kebiasaan sehingga penguasaannya harus melalui pembentukan kebiasaan tersebut, tetapi juga pada pandangan yang mengatakan bahwa bahasa itu diperoleh melalui pembentukan hipotesis berdasarkan masukan yang diterima pembelajar.

Pemerolehan bahasa dapat berupa pemerolehan bahasa pertama dan pemerolehan bahasa kedua atau ketiga. Pemerolehan bahasa pertama terjadi apabila kanak-kanak yang sejak semula tanpa bahasa kemudian memperoleh bahasa. Pemerolehan bahasa kedua terjadi apabila kanak-kanak atau orang dewasa yang telah menguasai bahasa pertama (bahasa ibunya), kemudian belajar bahasa kedua secara formal dan terencana. Pemerolehan bahasa pertama memiliki ciri kesinambungan dalam wujud suatu rangkaian kesatuan yang bergerak dari ucapan satu kata sederhana menuju gabungan kata yang rumit. Kemampuan kanak-kanak untuk menerima bahasa sejalan dengan perkembangan biologis tubuhnya, khususnya yang berkaitan dengan bagian-bagian pengucapan. Itulah sebabnya perkembangan bahasa kanak-kanak yang satu dengan yang lainnya juga berbeda walaupun usianya sama. Hal yang manarik dalam perkembangan pemerolehan bahasa pada kanak-kanak adalah kecepatan pemerolehannya tidak sama, tetapi tahap- tahapannya berlaku secara umum.

Kajian tentang pemerolehan bahasa mencakupi antara lain pemerolehan fonologi, morfologi, sistaksis, dan semantik. Sebagai salah satu kajian pemerolehan bahasa, pemerolehan fonologi merupakan ranah penelitian yang penting karena dapat menentukan atau mempengaruhi teori-teoiri linguistik. Kajian-kajian fonologi yang membahas kerumitan, keteraturan, dan keterbatasan sistem bunyi umumnya dapat menjadi penyokong dan penentu teori-teori linguistik yang dihasilkan oleh pakarnya. Hal lain yang menjadikan ranah fonologi ini menarik untuk dikaji dalam pemerolehan bahasa kanak-kanak adalah karena pemunculan bunyi ini bersifat genetik. Dengan kata lain, munculnya suatu bunyi tidak dapat diukur dengan tahun atau bulan kalender karena perkembangan biologi manusia tidak sama. Dengan demikian pemerolehan bahasa setiap anak pasti memiliki variasi. Berdasarkan uraian di atas tampaknya penelitian tentang pemerolehan bahasa perlu dilakukan lebih banyak dan lebih mendalam.

Penelitian bahasa anak cukup banyak dilakukan peneliti lainnya, seperti penelitian pemerolehan bahasa anak yang dilakukan oleh Arfian Hikkmat Ramdan dari Pascasarjana Linguistik Universitas Pendidikan Indonesia. Penelitiannya terkait dengan pemerolehan aspek fonologis anak umur 3 tahun yang berinisial RA. Hasilnya bunyi frikatif [s] dan bunyi afrikat [c], bunyi afrikat berat [j], bunyi nasal alveopalatal [n], dan bunyi getar [r] belum dapat diucapkan sempurna. Bunyi diftong [a-u] dan [a-i] belum munculnya (https://www. academia.edu/8894228/).

Selain itu, penelitian Kurniawan dari Universitas Mataram terhadap seorang anak berumur 2 tahun yang berinisial $M$ diakses dari http://jlt-polinema.org/?p=843. Hasil penelitiannya menyatakan banyak bunyi bahasa M yang dilesapkan dan diubah. Selanjutnya penelitian Hakim Usman yang meneliti putrinya berinisial ZR berumur 4 tahun, tetapi yang dikaji adalah aspek sintaksis anak. Hasilnya bahwa dalam bertutur ZR sudah mengenal dialog, perkembangan fonologinya sudah berakhir, dan kalimat yang diujarkan ZR banyak berbentuk deklaratif (http://jtt-polinema.org/?p=848).

Artikel ini membahas khususnya aspek fonologi TPM, anak penulis sendiri, pada usia 
2 tahun sampai dengan 2 tahun 6 bulan yang mencakupi pemerolehan vokal dan konsonan. Usia tersebut berada pada masa periode kritis (critical period) yang sangat penting dalam pemerolehan bahasa, juga karena pada usia tersebut TPM sangat aktif berbicara dan selalu ingin tahu tentang sesuatu hal.

Berdasarkan uraian di atas, artikel ini mendeskripsikan pemerolehan bahasa anak dilihat dari aspek fonologi atau sistem bunyi bahasa Indonesia. Masalah tersebut dibatasi pada hal-hal berikut: (a) bagaimana pemerolehan vokal pada anak usia 2 tahun sampai dengan 2 tahun 6 bulan? (2) bagaimana pemerolehan konsonan pada anak usia 2 tahun sampai dengan 2 tahun 6 bulan? (3) faktor apa yang mempengaruhi pemerolehan fonologi anak pada usia tersebut?

Istilah pemerolehan (acquisition) berbeda dengan pembelajaran (learning). Krashen (1983: 1-2) mengatakan bahwa pemerolehan adalah proses ambang sadar yang identik dengan proses yang dilalui anak dalam memperoleh bahasa ibunya, pemeroleh bahasa biasanya tidak sadar bahwa ia tengah memperoleh bahasa, tetapi ia hanya sadar bahwa ia tengah menggunakan bahasa untuk komunikasi; sedangkan pembelajaran adalah proses sadar yang menghasilkan pengetahuan tentang bahasa. Pendapat yang hampir sama disampaikan Dardjowidjojo (2012: 225) yang mengatakan bahwa pemerolehan adalah proses penguasaan bahasa yang dilakukan oleh anak secara natural pada waktu dia belajar bahasa ibunya (native language), sedangkan pembelajaran merupakan proses dari orang yang belajar di dalam kelas dan diajar oleh seorang guru.

Sementara itu, Galinkoff (1983:22) mengatakan bahwa ada dua pengertian yang perlu dipahami tentang pemerolehan bahasa. Pengertian pertama mengatakan bahwa pemerolehan bahasa mempunyai suatu permulaan yang tiba-tiba dan mendadak, sedangkan pengertian kedua mengatakan bahwa pemerolehan bahasa memiliki suatu permulaan yang gradual yang muncul dari prestasi-prestasi motorik, sosial, dan kognitif pralinguistik. Pandangan yang tidak jauh berbeda juga disampaikan Ellis (1985) yang mengatakan bahwa pemerolehan bahasa itu dilandasi oleh asumsi mengenai penguasaan bahasa yang bersifat bertahap (gradable) dan terkait unsur mengetahui (knowing).
Pandangan pakar di atas memperlihatkan bahwa pemerolehan bahasa merupakan proses yang berlangsung di dalam otak seseorang, terutama kanak-kanak, ketika dia memperolah bahasa pertamanya atau bahasa ibunya; sedangkan pembelajaran bahasa berkaitan dengan prosesproses yang terjadi pada waktu seseorang mempelajari bahasa kedua di lingkungan formal yang telah terencana.

Pemerolehan bahasa pertama merupakan pemerolehan bahasa yang terjadi apabila anak yang belum pernah belajar bahasa apapun sekarang baru mulai belajar bahasa untuk pertama kali (Klein, 1984: 6). Ada dua proses yang terjadi ketika seorang kanak-kanak sedang memperoleh bahasa pertamanya, yaitu proses kompetensi dan proses performasi. Proses kompetensi merupakan proses penguasaan tata bahasa yang berlangsung secara alamiah atau tanpa disadari. Proses kompetensi ini menjadi syarat terjadinya proses performansi yang terdiri atas proses pemahaman dan proses penghasilan. Proses pemahaman melibatkan kemampuan mengamati atau mempersepsi katakata atau kalimat yang didengar, sedangkan proses penghasilan melibatkan kemampuan mengeluarkan atau mengahasilkan kata-kata atau kalimat.

Sementara itu, Mukalel ( 2003) menyebutkan bahwa pemerolehan bahasa pertama adalah sekumpulan bahasa yang diperoleh anak sebelum usia sekolah. Pemerolehan bahasa pertama bersifat spontan, jarang dirancang dan direncanakan (Brown, 2007). Pemerolehan bahasa pertama terjadi secara alamiah. la menganggap bahwa biasanya pemerolehan bahasa pertama dikondisikan dengan memperkokoh hal yang bersifat primer seperti kebutuhan untuk mengkomunikasikan keinginan dan untuk membina hubungan afektif dengan orang tua. Jika dikaitkan dengan urutan pemerolehan, pengenalan anak dengan bahasa dapat terjadi melalui interaksi dengan orang tua, anggota keluarga lainnya, teman-teman sebaya di rumah atau di sekolah. Ketiga interaksi yang terjadi di dalam pemerolehan bahasa pertama itu kebanyakan terjadi secara alamiah

Dalam proses pemerolehan dan pembelajaran bahasa pertama pada anak, Hamied (1989: 24-30), diilhami oleh Ellis, mengatakan bahwa usia, seks, kelas sosial, dan identitas etnis merupakan faktor sosial yang sangat berpengaruh. Lebih jauh ia menganggap bahwa faktor yang berpengaruh dalam 
proses pemerolehan dan pembelajaran bahasa pertama selain faktor eksternal juga faktor internal. Faktor eksternal meliputi faktor sosial dan faktor masukan atau interaksi; sedangkan faktor internal mancakupi faktor transfer, unsur kognitif, dan faktor semesta.

Dengan demikian dapat dipahami bahwa pemerolehan bahasa pertama adalah suatu proses bagaimana anak memperoleh kemampuan bahasa ibunya secara alamiah sesuai dengan perkembangan kognitif, interaksi sosial, dan perkembangan linguistik anak itu sendiri.

Pemerolehan fonologi merupakan salah satu bagian dari pemerolehan bahasa. Oleh karena itu, penelitian tentang pemerolehan fonologi tidak dapat dipisahkan dari kajian-kajian tentang pemerolehan bahasa yang lain (pemerolehan morfologi, sistaksis, dan semantik). Dale (1976:7) mengatakan bahwa ada dua faktor yang dapat diikuti jika kita ingin memahami perkembangan fonologi kanak-kanak. Pertama, kita dapat memusatkan perhatian pada sekumpulan bunyi-bunyi yang dipakai dan pada perkembangan perlahan-lahan dari kumpulan bunyibunyi. Kedua, kita dapat meneliti hubungan antara produksi ucapan si anak (representasi fonetiknya) dengan kata yang coba diucapkan si anak. Untuk kepentingan itulah, kita dapat merekam apa yang diucapkan si anak. Data yang diperoleh dari hasil rekaman ditranskripsikan, kemudian diamati dan dianalisis secara empiris. Lebih jauh Dale (1976:9) mengatakan bahwa jika seorang anak telah mengucapkan suatu kata dalam situasi komunikasi tertentu dan dapat dipahami oleh lingkungannya, maka disimpulkan bahwa anak tersebut telah menguasai bunyi bahasa tersebut.

Sementara itu, Jakobson (1971: 8-20, dan dalam Dardjowidjojo, 2012) mengatakan bahwa pemerolehan bahasa pada anak sejalan dengan konsep universal pemerolehan fonologi. Pemerolehan bunyi berjalan selaras dengan kodrat bunyi itu sendiri dan diperoleh anak melalui suatu cara yang konsisten. Bunyi pertama yang dikuasai anak adalah kontras bunyi vokal dan konsonan. Dalam hal bunyi vokal terdapat tiga vokal utama yang muncul terlebih dahulu, yaitu [i], [u], dan [a]. Sistem kontras seperti itu disebut sistem vokal minimal (minimal vokalic system) dan terdapat dalam semua bahasa. Artinya, dalam bahasa mana pun ketiga bunyi vokal tersebut pasti ada. Dalam hal bunyi konsonan kontras pertama yang muncul adalah antara bunyi oral dengan bunyi nasal ([p-b], [m-n]) dan kemudian disusul oleh kontras antara bunyi bilabial dengan bunyi dental ([p], [t]). Sistem kontras seperti ini dinamakan sistem konsonantal minimal (minimal consonantal system). Lebih jauh Jacobson mengatakan bahwa hubungan antara bunyi yang satu dengan bunyi yang lain bersifat universal.

Dengan demikian tampak bahwa pemerolehan bunyi-bunyi bahasa itu berlangsung secara berurutan. Vokal minimal akan diperoleh lebih awal daripada vokal-vokal lainnya; sedangkan konsonan hambat akan diperoleh lebih awal daripada konsonan frikatif, dan konsonan frikatif akan diperoleh lebih awal daripada afrikatif. Anak tidak mungkin dapat menguasai frikatif atau afrikat sebelum mereka menguasai konsonan hambat. Kontras antara bilabial [b] dengan dental [d] dikuasai lebih dahulu daripada antara bilabial [b] dengan velar [g] atau dental [d] dengan velar [g]. Kontras antara bilabial-dental [b-d] dikuasai sebelum frikatif [v-s]; bunyi hambat dan frikatif [b-d-v-s] dikuasai sebelum alveo-falatal [ts-dэ]. Hal itu sejalan dengan apa yang disampaikan Ingram (1999) yang menyatakan bahwa konsonan pertama yang dikuasai anak adalah [p], [t], [m], [n].

Berdasarkan uraian di atas dapat disimpulkan bahwa pemerolehan bunyi bahasa pada kanakkanak berlangsung secara berurutan, yakni dari bunyi yang mudah ke bunyi yang sukar. Dalam pemerolehan fonologi, khususnya pemerolehan bunyi-bunyi, kanak-kanak mengikuti Kaidah Usaha Minimal (the Law of Least Efforts). Untuk mengetahui mudah atau sukarnya suatu bunyi, dasar yang digunakan adalah cara artikulasinya dan jumlah fitur distingtif yang ada pada masingmasing bunyi. Jika makin sukar artikulasi dan makin banyak fitur distingtifnya, makin belakangan bunyi itu dikuasai.

Kent dan Miolo (dalam Dardjowidjono, 2012:268) mengatakan bahwa melalui saluran intrauterine anak telah terekspos pada bahasa ketika dia masih janin. Kata-kata ibunya yang dia dengar masuk ke janin secara biologis. Kata-kata tersebut mulai tertanam dan melekat pada anak sebelum dia dilahirkan. Itulah sebabnya ada anggapan bahwa anak lebih dekat kepada ibunya darapada kepada ayahnya. Perkembangan bahasa anak yang dimulai sebelum dia dilahirkan itu sejalan dengan perkembangan pikiran, perasaan, sosial, dan lain- 
lain. Oleh karena itu, bahasa anak pun telah memiliki fungsi komunikasi sebagaimana bahasa orang dewasa. Meskipun demikian, fungsi-sungsi bahasa itu masih sangat terbatas karena perkembangannya sangat bergantung pada kemampuan kognitif, usia, dan lingkungan.

Bahasa anak memiliki beberapa tahapan. Bahasa anak pada tahap maraban pertama (pralinguistik I) ditandai dengan mendekur, menangis, atau menjerit. Tahap maraban kedua ditandai dengan letupan pola suku kata; tahap holofrastik (linguistik I) ditandai dengan ucapan-ucapan yang merupakan frasa atau kata-kata tertentu (biasanya pada anak usia 2 tahun). Tahap linguistik II ditandai dengan ucapan-ucapan dua kata. Tahapan linguistik III ditandai dengan perkembangan tata bahasa. Tahap liguistik IV ditandai dengan tata bahasa yang lebih rumit (menjelang dewasa). Sedangkan tahap kompetensi lengkap yang merupakan tahap akhir masa-masa kanak-kanak ditandai dengan struktur sintaksis yang mendekati bahasa ibunya (Tarigan, 1985:263-268).

Sementara itu, Mackey (dalam Fishman, 1972) mengatakan bahwa pemerolehan bahasa pertama itu terjadi selama periode kritis (critical period), yaitu pada usia $2-12$ tahun. Sehubungan dengan itu, ia menyusun kronologis perkembangan bahasa kanak-kanak. Pada usia 3 bulan, anak mulai mengenal suara manusia, ingatan sederhana mungkin sudah muncul, dan anak mulai tersenyum dan membuat suar-suar yang belum teratur. Pada usia 6 bulan anak sudah mulai bisa membedakan antara nada yang halus dan nada yang kasar, dan sudah mulai membuat vokal a...a...a. Pada usia 9 bulan, anak mulai bereaksi terhadap isyarat dan mulai mengucapkan bermacam-macam suara. Pada usia 12 bulan, anak bereaksi terhadap perintah dan gemar sekali membuat suara-suara. Pada usia 18 bulan, anak sudak mulai bisa mengikuti petunjuk, kosakatanya sudah mencapai dua puluhan, dan komunikasi dengan menggunakan bahasa sudah mulai tampak.

Berdasarkan tahapan-tahapan pemerolehan bahasa tersebut tampaknya anak usia 2 tahun sampai dengan 2 tahun 6 bulan yang menjadi subjek penelitian ini berada pada tahap keempat, yaitu tahap linguistik II.

\section{METODE PENELITIAN}

Metode yang digunakan dalam penelitian ini adalah metode kualitatif dengan pendekatan studi kasus. Melalui metode kualitatif ini akan dideskripsikan pemerolehan dan perkembangan fonologi TPM pada usia 2 tahun sampai dengan 2 tahun 6 bulan. Desain penelitian yang digunakan adalah longitudinal, yaitu dengan cara mengikuti perkembangan bahasa TPM dari suatu titik tertentu ( 2 tahun) sampai ke titik waktu yang lain (2 tahun 6 bulan).

Sumber data utama penelitian ini adalah TPM pada usia 2 tahun sampai dengan 2 tahun 6 bulan dan sumber data pendukung adalah orang tua TPM. Data ini dikumpulkan selama enam bulan melalui observasi, catatan harian, dan wawancara antara TPM dengan ayah dan bundanya, Bibi, Uni, dan Om. Hasil observasi dan wawancara itu dicatat dan direkam. Data tersebut kemudian ditranskripsikan, lalu diamati dan dianalisis secara empiris. Selanjutnya data yang sudah diperoleh, diklasifikasikan sesuai dengan masalah yang menjadi fokus penelitian.

Jika si anak telah mengucapkan suatu kata dalam situasi komunikasi tertentu dan dipahami maknanya oleh lawan bicaranya, disimpulkan bahwa si anak telah menguasai bunyi bahasa tersebut. Selanjutnya data yang sudah diperoleh, diklasifikasikan berdasarkan kelompok pemerolehan fonologi dan dikaitkan dengan pandangan para ahli yang menyatakan bahwa pemerolehan bahasa mengikuti proses yang bertolak dari sesuatu yang mudah menuju ke yang lebih sukar, sehingga setiap anak pada dasarnya memperoleh elemen-elemen bahasa dengan mengikuti gradasi kesukaran.

\section{HASIL DAN PEMBAHASAN}

Pada usia 2 tahun sampai dengan 2 tahun 6 bulan ini TPM tumbuh menjadi gadis cilik yang sehat, baik fisik maupun mental. Dalam kesehariannya selain berkomunikasi dengan orang tuanya, dia juga telah dapat berkomunikasi dengan orang lain, seperti keluarga dari pihak ayahnya atau ibunya, tetangga, dan teman-teman seusianya. Selain itu, anak ini juga sering diajak ke tempat keluarga jika ada acara keluarga dan ke tempat bundanya mengajar, sehingga masukan perkembangan 
pemerolehan bahasanya cukup bervariasi.

\section{Pemerolehan Vokal}

Bunyi-bunyi vokal yang muncul berdasarkan pengamatan data yang diperoleh selama 6 bulan adalah sebagai berikut.

Bunyi vokal [a] merupakan bunyi huruf pertama yang dikuasai TPM secara utuh. Bunyi tersebut muncul dan dilafalkan dengan jelas, baik yang terletak pada awal, tengah, maupun pada akhir kata. Bunyi vokal [a] di awal kata muncul seperti pada kata berikut.

[a] [ada] 'ada' dan [Ayah] 'Ayah' Bunyi vokal [a] di tengah kata muncul seperti pada kata berikut.

[a] [mana] 'mana' dan [Tatak] 'Kakak' Bunyi vokal [a] di akhir muncul pada kata berikut.

[a] [apa] 'apa' dan [tsuka] 'suka' Bunyi vokal [i] muncul dan dilafalkan dengan jelas, baik yang terletak pada awal, tengah, maupun akhir kata. Bunyi vokal [i] di awal kata muncul seperti pada kata berikut.

[i] [itu] 'itu' dan [indomalet] 'indomaret' Bunyi vokal [i] di tengah kata muncul seperti pada kata berikut.

[i] [bibi] 'Bibi' dan [sendili] 'sendiri' Bunyi vokal [i] di akhir kata muncul seperti pada kata berikut.

[i] [beli] 'beli' dan [pelgi] 'pergi' Bunyi vokal [u] muncul dan dilafalkan dengan jelas, baik yang terletak pada awal, tengah, maupun akhir kata. Bunyi vokal [u] di awal kata muncul seperti pada kata berikut.

[u] [uni] 'uni'

Bunyi vokal $[u]$ di tengah kata muncul seperti pada kata berikut.

[u] [butan] 'bukan' dan [buta] 'buka'

Bunyi vokal $[u]$ di akhir muncul seperti pada kata berikut.

[u] [itu] 'itu' dan [mau] 'mau' Bunyi vokal [e] muncul dan dilafalkan dengan jelas, baik yang terletak pada awal, tengah, maupun akhir kata. Bunyi vokal [e] di awal kata muncul seperti pada kata berikut.

'memang'

[e] [enam] 'enam' dan [emang]

Bunyi vokal [e] di tengah kata muncul seperti pada kata berikut.

[e] [boneka] 'boneka' dan [dedek] 'dedek/ adik'

Bunyi vokal [e] di akhir kata muncul seperti pada kata berikut.

[e] [e-e] 'he-he'

Bunyi vokal [o] muncul dan dilafalkan dengan jelas, baik yang terletak pada awal, tengah, maupun akhir kata. Bunyi vokal [o] di awal muncul pada kata berikut.

[o] [om] 'Om' dan [oran] 'orang' Bunyi vokal [o] di tengah kata muncul seperti pada kata berikut.

[o] [bobok] 'tidur' dan [boneka] 'boneka' Bunyi vokal [o] di akhir muncul pada kata berikut.

[o] [kado] 'kado'

Bunyi vokal [ə] muncul dan dilafalkan dengan baik. Data yang diperoleh hanya pada suku pertama, seperti

[ə] [balum] 'belum'

Bunyi vokal $[\varepsilon]$ muncul dan dilafalkan dengan baik. Data yang diperoleh hanya pada suku terakhir, seperti

[ع] [monet] 'monyet'

Bunyi vokal [ग] muncul dan dilafalkan dengan baik. Data yang diperoleh hanya pada suku terakhir, seperti
[כ]
[ijo]
'hijau'

Bunyi vokal rangkap yang muncul adalah [au], [ai], [ue], dan [ua]. Bunyi vokal rangkap [au] muncul seperti pada kata berikut.

[au] [tau] 'tau' dan [mau] 'mau Bunyi vokal rangkap [ai] muncul seperti pada kata berikut.

[ai] [naik] 'naik' dan [baik] 'baik'

Bunyi vokal rangkap [ue] muncul seperti pada kata berikut.

[ue] [kue] 'kue'

Bunyi vokal rangkap [ue] muncul seperti pada kata berikut.

[ua] [uan] 'uang'

Bunyi diftong yang muncul dilafalkan dengan vokal adalah [au] dan [ai]. Bunyi diftong [au] muncul seperti pada kata berikut.

[au] [piso] 'pisau'

Bunyi diftong [ai] muncul seperti pada kata berikut.

[ai] [pake] 'pake'

Berdasarkan uraian dan contoh data di atas dapat dikatakan bahwa TPM sudah menguasai semua vonem vokal bahasa Indonesia. Vokal [a], [i], [u], [e], dan [o] dilafalkan dengan baik meskipun terletak pada awal, tengah, atau akhir kata. Variasi alofonik untuk masing-masing bunyi sudah 
ada, kecuali untuk [o] dan [e] yang merupakan wujud diftong [au] dan [ai]. Semua vokal bahasa Indonesia tersebut sudah dikuasai TPM pada saat berumur 2 tahun 1 bulan. Vokal pertama yang dikuasainya adalah vokal minimal, yaitu [a], [i], dan [u] sesuai yang dijabarkan oleh Dardjowidjojo, kemudian berkembang menguasai vokal depan

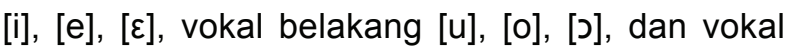
tengah $[\partial],[a]$. Tampaknya variasi alofonik yang tidak begitu kentara dalam Bahasa Indonesia tidak menimbulkan masalah bagi TPM dalam melafalkan bunyi-bunyi vokal. Pada usia 2 tahun 3 bulan TPM telah mengusai urutan vokal yang tidak bersifat diftong seperti [a-i] pada baik. Deretan vokal [a-u] seperti pada bau, [e-a] seperti pada kecapaian, [i-a] seperti pada sialan, dan [i-i] seperti pada diikat juga dikuasainya pada usia tersebut. Akan tetapi, diftong asli [au] dan [ai] seperti pada kalau dan sungai baru dikuasai TPM pada usia 2 tahun 6 bulan; sedangkan diftong asli [ji] yang jarang kita temukan belum muncul dalam pelafalan TPM.

\section{Pemerolehan Konsonan}

Pemerolehan bunyi kosonan TPM pada usia 2 tahun 5 bulan ini tidak semudah dia memahami pemerolehan bunyi vokal.

Bunyi letupan bilabial [p] dan [b] dilafalkan dengan jelas, baik yang terdapat di awal, di tengah, maupun di akhir kata seperti pada data berikut.

[p] [peldi] 'pergi' dan [dapat] 'dapat'

[b] [Bunda] 'Bunda' dan [bilu] 'biru'

Bunyi nasal bilabial [m] dan lamino-alviolar [n] dilafalkan dengan jelas, baik yang terdapat di awal, di tengah, maupun di akhir kata seperti pada data berikut.

[m] [mana] 'ke mana' dan [mau]'mau', [lumah] 'rumah'

[n] [boneta] 'boneka' dan [Bunda] 'Bunda' Bunyi hampiran bilabial [w] dan lamino palatal $[\mathrm{y}]$ dilafalkan dengan jelas, baik yang terdapat di awal, di tengah, maupun di akhir kata seperti pada data berikut. 'awas'

[w] [walna] 'warna' dan

[awas ]

[y] [Ayah] 'Ayah'

Bunyi letupan lamino-alveolar [t] dan [d] dilafalkan dengan jelas, baik yang terdapat di awal, di tengah, maupun di akhir kata seperti pada data berikut.

[t] [telus] 'terus' dan [nanti] 'nanti' [Adit] 'Adit'

[d] [Dedek] 'Dedek' dan [Saudara]
'Saudara'

Bunyi letupan dorso-velar [g] yang terletak di tengah dilafalkan dengan bunyi lamino-alviolar [d], tetapi jika bunyi terletak di awal dan akhir kata dilafalkan dengan baik seperti pada data berikut.

[d] [om Adus] 'om Agus' dan [badus] 'bagus'

[g] [gajah] 'gajah'

Bunyi letupan dorso-velar [k] yang berposisi di awal atau di tengah kata dilafalkan dengan bunyi lamino-alveolar [t], tapi jika bunyi tersebut terletak di akhir kata dilafalkan [k] seperti pada data berikut.

[t] [temali] 'kemari' dan [tuda] 'kuda' [tue] 'kue' [buta] 'buka' [matan] 'makan' dan [belatan]

'belakang'

[k] [Tatak] 'Kakak'

Pada usia 2 tahun 5 bulan bunyi [k] yang terletak di tengah sudah dilafalkan dengan benar, misalnya kakak dilafatkan [takak].

Bunyi afrikat palatal [c] jika terletak di awal kata dilafalkan dengan tepat, tetapi jika bunyi tersebut terletak di tengah dilafalkan dengan [t] seperti data berikut.

[t] [cutup] 'cukup' dan [celita] 'cerita'

[c] [kuting] 'kucing'

Bunyi afrikat palatal [j] kadang-kadang dilafalkan dengan baik dan kadang-kadang dilafalkan hambat labiodental [d] seperti pada data berikut.

[j] [juda] 'juga' dan [ijo]'hijau'

[d] [danan] 'jangan'

Bunyi frikatif lamino-alviolar [s] kadang-kadang dilafalkan dengan jelas dan kadang-kadang dilafalkan menjadi hambat labiodental [t], dan bunyi frikatif [z] dilafalkan [j] seperti pada data berikut.

[s] [masih] 'masih' dan [tampus] 'kampus' [t] [tsuka] 'suka' dan [tekolah]

'sekolah'

[i] [Jali] 'Rozali'

Bunyi frikatif glotal [h] muncul jika pada akhir kata seperti pada data berikut.

[h] [udah] 'sudah' dan [lumah]'rumah' [melah] 'merah' dan [tuh] 'tuh/itu' [nih] 'nih/ini'

Bunyi frikatif glotal [h] tidak muncul jika pada awal kata seperti pada data berikut.

[itam] 'hitam dan [ampil] 'hampir'

[abis] 'habis'

Bunyi nasal lamino-palatal [n?] dilafalkan menjadi nasal lamino-alveolar [n] seperti pada data berikut. 
[puna] 'punya' dan [nani] 'nyanyi'

Bunyi nasal dorso-velar [ $\mathrm{\eta}$ ] pada suku kata akhir diucapkan dengan jelas seperti pada data berikut.

[j] [walun] 'warung' dan [kunin] 'kuning'

Bunyi getar [r] belum muncul. Oleh karena itu, bunyi tersebut dilafalkan dengan bunyi sampingan atau lateral [l] seperti pada data berikut.

\section{[balu] 'baru' dan [bilu] 'biru' [lumah]'rumah'}

Pada usia 2 tahun sampai dengan 2 tahun 6 bulan ini tampaknya ada konsonan yang telah dikuasai TPM dengan baik dan dilafalkan dengan jelas; ada pula konsonan yang telah dikuasai tetapi masih berfluktuasi dengan bunyi lain dan bahkan ada bunyi yang sama sekali belum dikuasainya. Meskipun demikian, dalam mengucapkan fonemfonem tertentu hasil observasi memperlihatkan bahwa TPM sering melakukan pola substitusi. Pola substitusi yang muncul adalah sebagai berikut.

Getar menjadi lateral, misalnya

$\begin{array}{lll}\text { [rumah] } & \rightarrow & \text { [lumah] } \\ \text { [lari] } & \rightarrow & \text { [lali] }\end{array}$

Alveopalatal nasal menjadi dental nasal, misalnya

$\begin{array}{lll}\text { [ñañi ] } & \rightarrow & \text { [nani] } \\ \text { [ñapu] } & \rightarrow & \text { [napu] }\end{array}$

Velar hambat berat menjadi bilabial hambat, misalnya

$\begin{array}{lll}\text { [bagus] } & \rightarrow & \text { [badus] } \\ \text { [gatal] } & \rightarrow & \text { [datal] }\end{array}$

Velar nasal pada awal dan tengah suku kata menjadi dental nasal, misalnya

$$
\begin{array}{lll}
\text { [buna] } & \rightarrow & \text { [bunga] } \\
\text { [numpet] } & \rightarrow & \text { [numpet] }
\end{array}
$$

Labiodental frikatif ringan pada awal suku kata menjadi bilabial hambat ringan, misalnya

$$
\text { [fanta] } \rightarrow \quad \text { [panta] }
$$

Dental frikatif ringan pada awal suku kata menjadi dental stop ringan atau dental frikatif ringan, misalnya

$\begin{array}{lll}\text { [sekolah] } & \rightarrow & \text { [tetolah] } \\ \text { [susu] } & \rightarrow & \text { [tsutsu] }\end{array}$

Berdasarkan uraian dan contoh data di atas tampaknya TPM sudah menguasai bunyi konsonan [p], [b], [t], [d], [h], [m], [n], [l], [w], [y], [k], [s], [n] pada umur 2 tahun 1 bulan. Bunyi [k], [s], [n] hanya dikuasai TPM jika terletak pada akhir kata. Pada usia tersebut TPM belum menguasai bunyi velar hambat ringan (voiceless velar stop), [k], jika terletak pada tengah dan akhir kata. Bunyi tersebut baru dikuasai TPM setelah berusia 2 tahun 5 bulan.
Bunyi velar hambat berat (voice velar stop), [g], masih sering diucapkan dengan [d], terutama jika muncul pada tengah seperti Adus 'Om Agus', tetapi jika terletak di awal dilafalkan dengan [g] seperti gatal. Bunyi frikatif [s] pada awal kata masih sering diucapkan sebagai [t] atau [ts], tetapi pada akhir kata dilafalkan dengan frikatif [s]. Pada usia 2 tahun 6 bulan bunyi afrikatif ringan [c] telah dilafalkan dengan baik seperti pada coba, dan menjelang usia 2 tahun 6 bulan bunyi-bunyi tersebut semakin jelas dan dilafalkan dengan baik. Sampai usia 2 tahun 6 bulan ini tampaknya TPM belum dapat melafalkan gugus konsonan, kecuali [mb] dan [ng] pada kata mbak dan nggak. Gugus konsonan tersebut semuanya dilafalkan dengan konsonan tunggal.

\section{Faktor yang Mempengaruhi Pemerolehan Fonologi}

Hasil observasi memperlihatkan munculnya berbagai variasi dalam pemerolehan fonologi sebagian besar disebabkan oleh belum sempurnanya alat ucap TPM. Meskipun penulis telah mencoba memancing (reatrive) konsonan yang belum muncul dalam pelafalannya, TPM tetap tidak mampu mengucapkan konsonan tersebut. Hal itu tampaknya sejalan dengan pendapat Lenneberg yang menyatakan bahwa perkembangan bahasa anak mengikuti perkembangan biologis yang tidak dapat ditawar-tawar. Seorang anak tidak dapat dipaksa atau dipacu untuk mengujarkan sesuatu bila kemampuan biologisnya belum memungkinkan. Sebaliknya, bila seorang anak secara biologis dapat mengujarkan sesuatu, dia tidak dapat pula dicegah untuk tidak melafalkannya.

Faktor lain yang berpengaruh dalam pemerolehan fonologi TPM adalah stimulus dari keluarga atau lingkungan sekitarnya. Beberapa data yang berhasil penulis peroleh memperlihatkan bunyi-bunyi tertentu muncul melalui peniruan (immitative speech), seperti pelafalan diftong [au] dan [ai] pada kata kata kalau, kerbau, dan pakai yang belum muncul dilafalkan TPM dengan [kebo], [kalo], dan [pake]. Tidak atau belum munculnya diftong-diftong ini tampaknya tidak saja disebabkan oleh kesulitan artikulasi, tetapi juga karena masukan yang diterima TPM memang sering berupa monoftong. Penutur disekitar TPM dalam kesehariannya memang melafalkan bunyi-bunyi tersebut sebagai monoftong ([kebo], [kalo], dan [pake]) sehingga dapat dipahami jika TPM juga melafalkannya dengan bunyi-bunyi monoftong pula. 
Penguasaan bunyi-bunyi vokal dan konsonan yang telah dicapai TPM pada usia 2 tahun sampai dengan 2 tahun 6 bulan dapat dilihat pada bagan vokal dan konsonan berikut. Fonem yang telah dikuasai ditulis dengan huruf biasa, yang masih berfluktuasi ditulis dengan huruf miring, dan yang belum dikuasai ditulis di dalam tanda kurung. Gambar 1 berikut adalah bagan vokal.

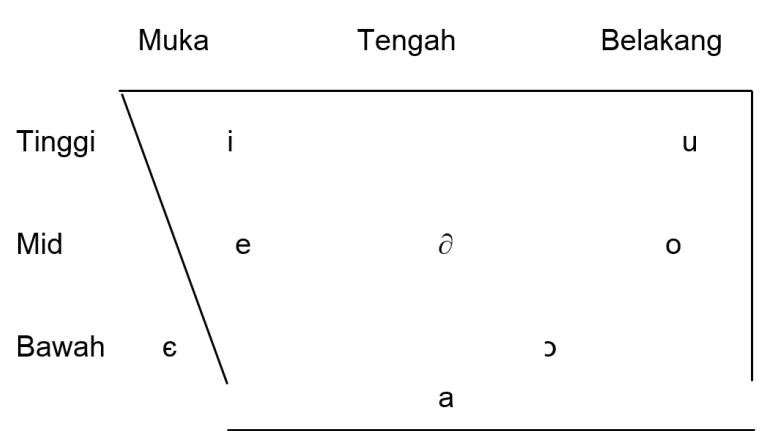

Gambar 1. Bagan vokal

Bagan pada gambar $1 \mathrm{di}$ atas memperlihatkan bahwa TPM telah menguasai fonem [a], [i], [u], [e],

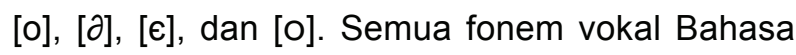
Indonesia itu dikuasai TPM pada usia 2 tahun 1 bulan. Dengan demikian, dapat dikatakan bahwa anak tersebut telah menguasai fonem vokal dengan baik. Artinya, orang tidak akan kesukaran memahami vokal mana yang dimaksud TPM. Vokal pertama yang dikuasainya adalah vokal minimal, yaitu [a], [i], dan [u], kemudian berkembang menguasai vokal depan [i], [e], [ع], vokal belakang

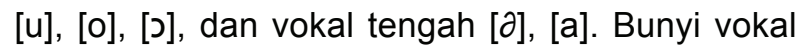
rangkap yang tidak bersifat diftong juga telah dikuasai pada usia 2 tahun 3 bulan, misalnya [au] pada [tau] 'tau' dan [ai] pada [baik] 'baik'; [ue] pada [kue] 'kue'. Akan tetapi, diftong asli [au] dan [ai] baru dikuasai TPM pada usia 2 tahun 6 bulan; sedangkan diftong asli [ji] yang jarang kita temukan belum muncul dalam pelafalan TPM sehingga dilafalkan dengan [e], misalnya [ai] pada 'pakai' dilafalkan [pake].

Penguasaan bunyi konsonan TPM tampaknya tidak semudah penguasaan bunyi vokal. Ada bunyi konsonan yang telah dikuasainya; ada yang masih berfluktuasi dengan bunyi lain; dan bahkan ada bunyi (bunyi [r]) yang belum pernah dapat dia ucapkan. Untuk lebih jelasnya, perhatikan Tabel 1 berikut.
Tabel 1. Penguasaan Bunyi Konsonan TPK

\begin{tabular}{lcccccc}
\hline \multirow{2}{*}{$\begin{array}{c}\text { Cara } \\
\text { Artikulasi }\end{array}$} & \multicolumn{6}{c}{ Daerah Artikulasi } \\
\cline { 2 - 7 } & Bilabial & $\begin{array}{c}\text { Labio- } \\
\text { Dental }\end{array}$ & Alveolar & $\begin{array}{c}\text { Alveo- } \\
\text { Palatal }\end{array}$ & Velar & Glotal \\
\hline Hambat & $\mathrm{P}$ & $\mathrm{t}$ & & & $(\mathrm{k})$ & $?$ \\
& $\mathrm{~b}$ & $\mathrm{~d}$ & & & $(\mathrm{~g})$ & \\
Frikatif & & $(\mathrm{f})$ & $\mathrm{s}$ & & $(\mathrm{x})$ & $\mathrm{H}$ \\
Afrikatif & & $(\mathrm{v})$ & $(\mathrm{z})$ & & & \\
Nasal & & & & $c$ & & \\
Lateral & $\mathrm{M}$ & & $\mathrm{N}$ & $(\mathrm{n})$ & & \\
Getar & & & & $\mathrm{L}$ & & \\
Semi Vokal & $\mathrm{W}$ & & & & & \\
\hline
\end{tabular}

Bagan konsonan di atas memperlihatkan bahwa fonem yang sudah dikuasai TPM dengan baik adalah [p], [b], [t], [d], [s], [h], [c], [j], [m], [n], [n], [l], [w], dan [y]. Bunyi letupan bilabial [p] dan [b], bunyi nasal bilabial [m] dan lamino-alviolar [n], bunyi hampiran bilabial [w] dan lamino palatal [y], dan bunyi letupan lamino-alveolar [t] dan [d] dilafalkan dengan jelas.

Konsonan yang sudah muncul tetapi masih berfluktuasi dengan bunyi lain adalah [t], [s], [c], [j], dan [n]. Jika bunyi frikatif lamino-alviolar [s] terletak pada akhir kata, diucapkan TPM dengan jelas. Akan tetapi, jika bunyi tersebut terletak pada awal suku kata, sering diucapkan [t] atau [ts], misalnya [abis] pada [habis] 'habis. Bunyi afrikatif berat [j] ada juga yang dilafalkan sebagai [d], misalnya [danan] pada [jangan] 'jangan'. Bunyi hambat velar [g] masih diucapkan sebagai hambat labiodental [d], dan hambat velar [k] dilafalkan dengan hambat labiodental [t], misalnya [badus] pada [bagus] 'bagus', [tamal] pada [kamar] 'kamar'. Bunyi velar hambat ringan (voiceless velar stop), [k] baru dikuasai jika terletak pada tengah dan akhir kata pada berusia 2 tahun 5 bulan. Pada usia 2 tahun 5 bulan bunyi afrikatif ringan [c] telah dilafalkan dengan baik seperti pada coba, dan menjelang usia 2 tahun 6 bulan bunyi-bunyi tersebut semakin jelas dan dilafalkan dengan baik. Bunyi frikatif [f] dan [v] belum muncul dan dikuasai TPM dengan baik sehingga dilafalkan dengan [p] seperti [panta] pada [fanta] 'fanta' dan [pas] pada [vas] 'vas bunga'. Bunyi frikatif $[\mathrm{x}]$ tidak ditemukan di dalam data sehingga dinggap belum muncul. Bunyi getar [r] yang belum muncul dilafalkan dengan bunyi lateral [l], misalnya [bilu] pada [biru] 'biru'. Kemampuan TPM melafalkan fonem [f], [v], [z], dan [x] belum 
kelihatan karena karena frekuensi penggunaannya dalam bahasa Indonesia sangat terbatas. TPM melakukan pola substitusi untuk mengucapkan fonem-fonem tertentu. Penggantian pola yang muncul mengukiti pola kedekatan fonetik (phonetic proximile), yaitu suatu bunyi diganti oleh bunyi lain yang secara fobetis berdekatan. Misalnya, bunyi getar menjadi lateral seperti [rumah] menjadi [lumah].

\section{PENUTUP}

\section{Kesimpulan}

Secara umum pemerolehan fonologi TPM mengikuti urutan yang sifatnya universal sesuai dengan teori pemerolehan bahasa. Konsep universal Jakobson (dalam Dardjowijojo, 2012: 238) ditemukan dalam pemerolehan fonologi TPM, baik dalam pemerolehan vokal maupun konsonan. Dalam hal bunyi vokal terdapat tiga vokal utama yang muncul terlebih dahulu, yaitu [i], [u], dan [a]. Sistem kontras seperti ini disebut sistem vokal minimal dan terdapat dalam semua bahasa. Dalam hal konsonan, hambat dikuasai sebelum frikatif, dan frikatif dikuasai sebelum afrikat. Bunyi nasal dimulai dari nasal bilabial [m], kemudian diikuti nasal velar [n]. Pemerolehan konsonan hambat dimulai dari bilabial ke alveolar, kemudian ke velar. Bunyi lateral [l] sudah dikuasai, sedangkan bunyi getar [r] belum. Bunyi likuid yang berupa lateral [l] muncul terlebih dahulu setelah bunyi hambat ringan, sedangkan bunyi [r] belum muncul karena diduga lebih sulit mengucapkannya. Hal itu memperlihatkan bahwa dalam pemerolehan fonologi juga mengikuti gradasi kesukaran fonologis.
Pemerolehan fonologi TPM sangat dipengaruhi (sejalan dengan) perkembangan biologisnya. Misalnya, karena kondisi alat ucap atau posisi lidahnya masih terbatas (belum lengkap) sehingga ia belum menguasai bunyi getar [r]. Selain itu, pemerolehan fonologi juga dipengaruhi oleh stimulus dari keluarga atau lingkungan. Misalnya disftong [au] dan [ai] pada kata [kalau] dan [pakai] dilafalkan TPM dengan [kalo] dan [pake].

\section{Saran}

Berdasarkan kesimpulan tersebut, terdapat beberapa saran. Pertama, pemerolehan bahasa anak selain factor fisik juga ditentukan oleh stimulus dari keluarga dan lingkungan. Oleh sebab itu, bagi orang tua yang ingin pemerolehan bahasa anaknya sesuai dengan perkembangan fisik, bahkan melampaui harus selalu diberi stimulus oleh orang tua dan lingkungan. Dengan demikian, pengaruh faktor eksternal berperan penting.

Kedua, penelitian ini masih terbuka luas dilakukan oleh peneliti-peneliti lainnya, karena pemerolehan bahasa setiap anak memiliki keunikan masing-masing. Selain itu, aspek penelitian pemerolehan bahasa anak juga beragam, yaitu dari aspek fonologi, sintaksis, morfologis, semantic, dan lain-lain

\section{DAFTAR PUSTAKA}

Bomerman, Melissa.,\& Lavinson, S. C. (2001). Language acquisition and conceptual development. New York: Cambridge University Prass.

Brown, D.(2007). Principles of learning and teaching. New Jersey: Printice Hand Reagent.

Dale, P.S. (1976). Language development: Structure and fuction. New York. Holt, Rinehart, and Watson.

Dardjowidjojo, S. (2012). Psikolinguistik: Pengantar pemahaman bahasa manusia. Jakarta: Yayasan Obor Indonesia.

Ellis, R. (1985). Understanding second language acquisition. London: Axford University Press.
Flecher, Paul.,\& Garmen, M. (1997). Language acquisition. New York: Cambridge University Press.

Galinkoff, R. M. (1983). The transition from prelinguistik to linguistic communication. Millsdale, New Jersey: Lawrence Erlbaum Association Publishers.

Hamied, F. A. (1989). Keterpelajar(i)an dalam konteks pemerolehan bahasa. Dalam PELLBA 2. Jakarta: Penerbit Kanisius.

Ingram. (1999). Phonological acquistion in the development (ed.) United Kongdom: Psycology Press.

Jacobson, R. (1971). Studies on child language and 
aphasia. The Hauge: Mouton Publishers.

Kent, R.D.,\& Miolo, G. (1995). Phonetic abilities in the first year of life. Dalam Fletcher dan Mac Whinney 1995.

Klein. (1984). Learning to stress. Journal of Child Language 11: 375-93/191. Indiana University.

Kurniawan. Studi kasus pemerolehan bahasa anak usia 2 tahun hasil pernikahan pasangan beda daerah: Kajian fonologi (Fonetik Artikulatoris). Diakses tanggal 14 Okteber 2016. http://jltpolinema. org $/ \mathrm{p}=843$

Krashen, S.,\& T. Terrell, (1983). The natural approuch: Language acquistion in the classroom. Oxford: Pergemon.
Mukalel, J. C.( 2003). Psychology of language learning. New Delhi: Discovery Publishing House

Pinker, S. (2004). Language acquisition. http://www. scs.soton.ac.uk/-harnad/Papers/Py104/Pinke. langaca.html.

Ramdan, A. H. Pemerolehan fonologi umur 3 tahun. Diakses 14 Oktober 2016. https://www. academia.edu/8894228/

Tarigan, H. G. (1988). Pengajaran pemerolehan bahasa. Jakarta: Direktorat Pendidikan Tinggi, Departemen Pendidikan dan Kebudayaan.

Usman, H. (2016). Studi pemerolehan bahasa anak usia 4 tahun. Diakses 14 Oktober 2016. http:// jlt-polinema. org $/ ? \mathrm{p}=848$ 